\title{
Occupational exposure to perchloroethylene in Portuguese dry-cleaning stores
}

\author{
S. Viegas \\ Escola Superior de Tecnologia da Saúde de Lisboa, \\ Instituto Politécnico de Lisboa (ESTeSL/IPL), Portugal
}

\begin{abstract}
Perchloroethylene (also known as tetrachloroethylene) is a solvent that has been a mainstay of the dry cleaning industry for decades. Since 1995 the International Agency for Research on Cancer considers that dry cleaning entails exposures that are possibly carcinogenic to humans (Group 2B). Meanwhile, the same institution classified perchloroethylene as probably carcinogenic to humans (Group 2A).

Some industries have begun using alternative cleaning methods that do not require the use of perchloroethylene. However, in Portugal this solvent is still the most common dry-cleaning agent.

An exploratory study was developed that aimed to find the occupational exposure to perchloroethylene in four Portuguese dry-cleaning stores. Activities involving higher exposure and variables that promote exposure were also investigated.

Real-time measurements of volatile organic compounds concentrations were performed using portable equipment (MultiRAE, RAE Systems model calibrated by isobutylene). Considering that perchloroethylene was the only cleaning product used in all the stores studied we deduce that results obtained for volatile organic compound measures correspond to perchloroethylene concentrations. The measurements were performed in the same places in each store and during the same tasks, namely: reception area, dry and washing area; iron area; dry-cleaning machine working; loading and unloading dry-cleaning machine and manual removing of stains with perchloroethylene. Besides measurements, information related with variables that can influence exposure in each store was also collected.
\end{abstract}


Results of volatile organic compounds concentrations range from $0.0 \mathrm{ppm}$ to $558 \mathrm{ppm}$. Three of the tasks studied obtained concentrations higher than 100 ppm, namely loading and unloading dry-cleaning machine and also manual removing of stains with perchloroethylene.

It was possible to identify tasks with priority for the appliance of preventive and protective measures. It seems that exposure to high perchloroethylene concentrations still occurs in Portuguese dry-cleaning stores and lack of ventilation conditions is probably the major cause of this situation.

Keywords: perchloroethylene, occupational exposure, dry-cleaning, ventilation conditions, real-time measurements.

\section{Introduction}

Dry cleaning is essentially a waterless process in which clothes are cleaned with an organic solvent rather than with soap and water. Early dry-cleaning solvents such as turpentine, gasoline, or benzene were flammable or explosive. Non flammable dry-cleaning solvents such as carbon tetrachloride, trichloroethylene, and fluorocarbons were introduced in 1900's. Perchloroethylene (PCE, tetrachloroethylene) introduced in the 1940s, has become the primary drycleaning solvent in use $[1,2]$.

Nowadays, perchloroethylene (PERC) is widely used in Portugal and in many other countries as a solvent in many commercial dry cleaning stores.

As an example, there are over 30.000 commercial dry-cleaning stores and approximately 244.000 dry-cleaning workers in the United States. Approximately 90 percent of these stores use PERC as their primary solvent $[3,4]$. Consequently, occupational exposure to PERC has already been demonstrated for dry cleaning workers [2, 5-10].

However, over the past several decades, the dry-cleaning industry has made tremendous progress in reducing workers' exposure and environmental releases of PERC. In particular, the dry-cleaning machines and solvents used have evolved over time. The development of dry-cleaning machines encompasses five "generations" [4].

The first generation of dry-cleaning machines were transfer machines with separate washers and dryers. Transfer machines, older and less expensive, require manual transfer of solvent laden clothing between the washer and dryer. The transfer activity involves high worker exposure to PERC. In the late 1960s the second generation, non refrigerated, dry-to-dry machines, using a one step process that eliminates clothing transfer, were introduced.

In dry-to-dry machines, clothes enter and exit the machine dry. Generally, worker exposure to PERC from dry-to-dry machines is less than exposure from transfer machines. Most second-generation machines are vented dry-to-dry machines that vent residual solvent vapours directly to the atmosphere or through some form of vapour recovery system during the aeration process. The third generation of machines, dry-to-dry machines with refrigerated condensers, was introduced in the late 1970 s and early 1980s. These machines are vent less dryto-dry machines that are essentially closed systems, which are only open to the 
atmosphere when the machine door is opened. They promote recirculation of the heated drying air through a vapour recovery system and back to the drying drum and because of that here is no aeration step. This machines generation provides considerable solvent savings over their predecessors. Fourth-generation drycleaning machines are essentially dry-to-dry, no vented machines having controls to reduce residual PERC concentrations in the machine cylinder at the end of the dry cycle. These dry-to-dry machines rely on both a refrigerated condenser and closed-loop carbon absorber that does not vent to the atmosphere to recover PERC vapours during the dry cycle. They are designed to recover residual PERC vapours in the cylinder at the end of the dry cycle. More traditional machines generally emit higher concentrations of PERC into the environment and workers' breathing zones. Fifth-generation machines have the same features as fourth-generation machines; however, they are also equipped with a monitor inside the machine drum connected to an interlock to ensure that the concentration is below approximately $290 \mathrm{ppm}$ before the loading door can be opened [4]. This can be considering a preventive measure to reduce exposure.

PERC vapours are rapidly absorbed through the pulmonary alveolar epithelium and are largely exerted by the same route. Elimination via exhaled breath is biphasic, probably because of storage and release from fatty tissues. Some dermal absorption may occur, but this is generally considered to be minimal. PERC is partially metabolized to trichloroacetic acid, which is exerted in urine. In humans, $80-100 \%$ of the absorbed perchloroethylene is exerted as the parent compound by exhalation $[2,11]$.

Regarding health effects, PERC inhalation can lead to depression of the central nervous system. Symptoms at various concentrations include unconsciousness, dizziness, headache, drowsiness, and visual disturbances. Irritation on the eyes, nose and throat may occur, and gastrointestinal complaints such as nausea and vomiting have been reported. Psycho-physiological effects include fatigue, anorexia, irritability, impaired memory, and confusion. Direct skin contact with liquid PERC may lead to erythema, burns, and vesiculation [8]. In the case of reproductive effects, general mechanisms have been suggested in literature for explaining the possible effect in reproduction, namely: Exposure may cause mutations or other genotoxic damage in the ova or sperm; Exposure may cause injurious effects on parental cells or cell systems, which are essential in the reproductive process (ova, sperm, ovaries, testes, prostate, endometrial tissue, hypothalamus, pituitary, etc ), or it can cause such effects on embryonic or foetal cells, tissues or organs; Exposure may act as an agonist or antagonist of endogenous hormones relevant to reproduction and, finally, exposure may disturb regulatory mechanisms important in reproduction. Each of these mechanisms should be considered as a potential action for PERC to interfere with reproduction $[12,13]$.

PERC has been shown to cause cancer in laboratory animals. This has raised the concern that it may also cause cancer in humans. Several epidemiological studies have been conducted to determine whether there is an association between occupational exposure to PERC and increased cancer risk. Unfortunately, these studies failed to control for smoking status or other factors 
contributing to cancer such as exposure to petroleum solvents (use some times to remove stains), hepatitis infection, alcohol abuse, and human papilloma virus infection [2, 11, 14] Nevertheless, since 1995 the International Agency for Research on Cancer classified PERC as probably carcinogenic to humans (Group 2A) [13].

The PERC Threshold Limit Value for the Time Weighted Average 8 hour day (TLV-TWA) recommended by the ACGIH is $25 \mathrm{ppm}\left(170 \mathrm{mg} / \mathrm{m}^{3}\right)$ [15]. The same is mention by the Portuguese Norm 1796 (2007) that recommend also $100 \mathrm{ppm}$ as Short Term Exposure Limit (TLV - STEL) [16].

This study was designated to evaluate workers exposure to VOCs in 4 drycleaning stores and also identify the task with higher exposure and, consequently, with priority for preventive measures application.

Considering that PERC was the only cleaning product use in all the stores studied we deduce that results obtains with VOCs concentrations measure correspond to PERC concentrations.

\section{Materials and methods}

This study was conducted in four dry-cleaning stores located in Lisbon that used only PERC has dry-cleaning agent.

The VOCs measurements were performed in the same places in each store and during the same tasks, namely: reception area, dry and washing area; iron area; dry-cleaning machine working; loading and unloading dry-cleaning machine and also manual removing of stains with PERC. Besides measurements in each store was collected information's about ventilation resources, drycleaning machine type (generation), number of loadings machine per day and use of individual protection equipment.

In this research, real-time measurements of VOCs concentrations were performed using portable direct-reading equipment ((MultiRAE, RAE Systems model-calibrated by isobutylene). The detection technique used in this equipment is Photo Ionization Detection (PID) equipment (10.6 eV lamps). The use of this equipment permitted to identify the worst case scenario concerning to exposure in the tasks studied.

The PID equipment was zeroed outside each store in fresh air prior to starting measurements. All measurements were done in the breathing zone of the workers while they were performing their tasks, during 5 to 15 minutes. It was consider the highest concentration obtained in each measurement point/task.

\section{Results}

The dry-cleaning stores were similar considering ventilation conditions. Only one store (D) doesn't have windows and works with a closed door. This store has also the higher number of loadings per day and it was the only one that had a dry-cleaning machine from $3^{\text {rd }}$ generation.

Regarding ventilation conditions, store A was the only one that doesn't have mechanical general ventilation. Meanwhile, none of the stores have located 
ventilation. All the stores have acclimatization. Concerning manual removing of stains with PERC, only store C doesn't have this practice.

In dry-cleaning stores $\mathrm{A}$ and $\mathrm{B}$ measurements were performed in the morning, and in dry-cleaning stores $\mathrm{C}$ and $\mathrm{D}$ in the afternoon. Results of VOCs concentrations range from $0.0 \mathrm{ppm}$ to $586 \mathrm{ppm}$ (Table 2).

Table 1: $\quad$ Characterization of each dry-cleaning store.

\begin{tabular}{|c|c|c|c|c|}
\cline { 2 - 5 } \multicolumn{1}{c|}{} & A & B & C & D \\
\hline Number of loadings per day & 4 & 4 & 2 & 5 \\
\hline Open doors & Yes & Yes & Yes & No \\
\hline Windows & Yes & No & Yes & No \\
\hline $\begin{array}{c}\text { General ventilation } \\
\text { cleaning machine door }\end{array}$ & No & Yes & Yes & Yes \\
\hline $\begin{array}{c}\text { Located ventilation outside } \\
\text { in dry-cleaning machine }\end{array}$ & No & No & No & No \\
\hline $\begin{array}{c}\text { Climatization sistem } \\
\text { Nocated ventilation in dry- }\end{array}$ & Yes & Yes & Yes & Yes \\
\hline Machine generation & $4^{\text {th }}$ & $4^{\text {th }}$ & $4^{\text {th }}$ & $3^{\text {rd }}$ \\
\hline $\begin{array}{c}\text { Manual removing of stains } \\
\text { with PERC }\end{array}$ & Yes & Yes & No & Yes \\
\hline $\begin{array}{c}\text { Individual Protection } \\
\text { Equipment use }\end{array}$ & No & No & No & No \\
\hline
\end{tabular}

Table 2: $\quad$ Results of VOCs measurements (ppm).

\begin{tabular}{|c|c|c|c|c|c|c|c|}
\hline Stores & $\begin{array}{c}\text { Reception } \\
\text { area }\end{array}$ & $\begin{array}{c}\text { Dry and } \\
\text { washing } \\
\text { area }\end{array}$ & $\begin{array}{c}\text { Iron } \\
\text { area }\end{array}$ & $\begin{array}{c}\text { Dry- } \\
\text { cleaning } \\
\text { machine } \\
\text { working }\end{array}$ & $\begin{array}{c}\text { Loading dry- } \\
\text { cleaning } \\
\text { machine }\end{array}$ & $\begin{array}{c}\text { Unloading } \\
\text { dry- } \\
\text { cleaning } \\
\text { machine }\end{array}$ & $\begin{array}{c}\text { Manual } \\
\text { removing } \\
\text { of stains } \\
\text { with } \\
\text { PERC }\end{array}$ \\
\hline A & 0.5 & - & 6.8 & 2.3 & 586 & 88.9 & - \\
\hline B & 0.0 & 0.3 & 1 & 0.9 & 277 & 46.7 & - \\
\hline C & 12.1 & 26.1 & 52.7 & 20.1 & - & 229 & - \\
\hline D & 0.1 & 0.0 & 3.8 & 4.6 & 90.6 & 83.4 & 122 \\
\hline
\end{tabular}




\section{Discussion}

In dry-cleaning stores, release of PERC vapours into the environment and subsequent worker exposure to PERC vapours is greatest during loading, unloading and also maintenance of dry-cleaning machine [17]. This is consistent with our results, however, only this last task wasn't possible to study in this research. Results obtained show various tasks with concentrations higher than 100 ppm (Short Term Exposure Limit) and the majority of tasks have duration's superior to 15 minutes, namely loading and unloading dry-cleaning machine and manual removing of stains.

Additionally, a previous study demonstrated also that machine operators have the greatest PERC exposure probably because they execute the loading and unloading of dry-cleaning machine [2].

In the case of unloading, probably exposures can be reduce if fifth-generation machines were used because they have a monitor inside the machine drum connected to an interlock to ensure that the concentration is below approximately 290 ppm before the machine door can be opened [4].

Other tasks show high VOCs concentrations results, namely iron and manual removing of stains. Probably, results in first task $(52.7 \mathrm{ppm})$ are due to temperature increase that promotes volatilization of PERC residues presents in clothes. In the second task, stains removing, only studied in store D, the short distance from the worker breathing zone to the clothe surface, when applying the PERC, explains the obtained results (122 ppm).

Furthermore, it is important to notice that store A was the only one that doesn't have mechanical general ventilation, and this contributes to the vapour accumulation inside the store and might explain the higher concentration (586 ppm) obtain during dry-cleaning machine loading. This kind of ventilation (general promotes dilution and is very useful in decreasing the contamination in work places $[2,17,18]$. Generally accepted guidelines recommend an air change in the workroom every five minutes with a minimum of $30 \mathrm{cfm}$ of outside air per person. Supply and exhaust systems within the store should move air from a clean area (offices, reception area, etc.) to less clean area (where the dry-cleaning machine is located) [17]. Moreover, none of the studied stores have local exhaust ventilation and this ventilation technique is fundamental to reduce the vapour level reaching the worker's breathing zone and minimizes also vapour diffusion [17].

Concerning the exposure assessment method applied, it is important to consider that knowing when high exposures occurs permit to identify the tasks and work conditions that promote exposure and where the investments have more impact in the workers safety. Therefore, identifying the task with higher peak concentration is extremely important to perform health risk assessment and to define priorities for the appliance of preventive and protective measures. Additionally, the development of real-time measurements offers the possibility of directly relate performance with exposure [19]. This kind of measurement resource is well describe in a study performed by Viegas et al. [20] that also permitted to identify the tasks that involve higher peak exposure to formaldehyde 
in ten pathology and anatomy laboratories and one formaldehyde-based resins production factory.

Moreover, peak exposures are a special concern because high concentration produces a high dose rate into the body and target tissue, which may alter metabolism, overload protective or repair mechanisms, and amplify tissue responses. Therefore, is important to characterize peak exposures, because a peak can produce more and perhaps different health effects than the same administered dose given with less intensity over a longer time period [21-23].

\section{Conclusions}

The results obtained are not detailed in the PERC exposure in this occupational setting; however it brings attention for the exposure characteristics (peak exposure) during some of the tasks. More detailed studies have to be developed with the complementary use of exposure biomarkers. Meanwhile the data obtained can support the adoption of some preventive measures, namely replacement of old machines with fifth-generation machines and improve of ventilation conditions (local and general).

\section{References}

[1] Solet, D, Robins, TG, Sampaio C, Percloroethylene exposure assessment among dry cleaning workers. Am Ind Hyg Assoc J. 51 (1990) 566-74.

[2] Pirsaraei, A, Khavanin, A, Asilian, H, Soleimanian, A, Occupational Exposure to Perchloroethylene in Dry-cleaning Shops in Tehran, Iran. Industrial Health. 47 (2009) 155-159.

[3] Environmental Protection Agency. Economic Impact Analysis of Regulatory Controls in the Dry Cleaning Industry. EPA 450/3-91-021. Office of Air Quality Planning and Standards, EPA, Research Triangle Park, NC (1991).

[4] Earnest, G, A Control Technology Evaluation of State-of-the-Art, Perchloroethylene Dry-Cleaning Machines. Applied Occupational and Environmental Hygiene. 17 (2002) 352-359.

[5] Verberk, M, Scheffers, T, Tetrachloroethylene in exhaled air of residents near dry-cleaning shops. Environ. Res. 21 (1980) 432-437.

[6] Lauwerys, R, Herbrand, J, Buchet, A, Gaussin, B, Gaussin, J, Health surveillance of workers exposed to tetrachloroethylene in dry-cleaning shops. Int. Arch. Occup. Environ. Health. 52 (1983) 69-77.

[7] Monster, A, Regouin-Peeters, W, Van Schijndel, A Van Der Tuin, J, Biological monitoring of occupational exposure to tetrachloroethene. Scand. J. Work Environ. Health. 9 (1983) 273-281.

[8] Materna, M, Occupational exposure to perchloroethylene in the dry cleaning industry. Am. Ind. Hyg. Assoc. J. 46 (1985) 268-273.

[9] Droz, P, Guillemin, M, Occupational exposure monitoring using breath analysis. J. Occup. Med. 28 (1986) 593-602. 
[10] Thompson, K, Evans, J, Workers' breath as source of perchloroethylene (PERC) in the home. J. Expos. Anal. Environ. Epidemiol. 3 (1993) $417-$ 430.

[11] ATSDR. Toxicological Profile for Tetrachloethylene. Agency for Toxic Substances and Disease Registry. US. Department of Health and Human Services. 1997.

[12] Gulden, J, Zielhuis, G, Reproductive hazards related to perchloroethylene. A review. Int Arch Occup Environ Health 61(1989) 235-242.

[13] International Agency for Research on Cancer, Dry cleaning, some chlorinated solvents and industrial chemicals. Lyon: IARC, 1995

[14] Ruder, A, Ward, E, Brown, D, Mortality in Dry-Cleaning Workers: An Update. American Journal of Industrial Medicine. 39 (2001) 121-132.

[15] American Conference of Governmental Industrial Hygienists, Threshold limit values for chemical substances and physical agents and biological exposure indices (TLVs and BEIs), ACGIH, Cincinnati, (2006).

[16] Instituto Português da Qualidade - NP 1796 : 2007 : segurança e saúde do trabalho : valores limite de exposição profissional a agentes químicos existentes no ar dos locais de trabalho. Caparica: IPQ, 2007.

[17] National Institute for Occupational Safety and Health. Control of Exposure to Perchloroethylene in Commercial Drycleaning (Ventilation). Applied Occupational and Environmental Hygiene. 15 (2000) 187-188.

[18] Liddament, M, A review of ventilation and the quality of ventilation air. Indoor Air. 10 (2000) 193-199.

[19] Walsh, P, Forth, A, Clark, R, Real-time measurement of dust in the workplace using video exposure monitoring: farming to pharmaceuticals. Journal of Physics : conference series. 151 (2009) 012-043.

[20] Viegas, S, Ladeira, C, Nunes, C, Malta-Vacas, J, Gomes, M, Brito, M, Mendonça, P, Prista, J, Genotoxic effects in occupational exposure to formaldehyde: A study in anatomy and pathology laboratories and formaldehyde-resin production. Journal of Occupational Medicine and Toxicology. (2010) 5:25. http://www.occup-med.com/content/5/1/25.

[21] Smith, T, Studying peak exposure: toxicology and exposure statistics. In: Marklund, S, ed. lit. - Exposure assessment in epidemiology and practice. Stockholm: National Institute for Working Life. (2001) 207-209.

[22] Preller, L, Burstyn, I, De Pater, N, Characteristics of peaks of inhalation exposure to organic solvents. The Annals of Occupational Hygiene. 48 (2004) 643-652.

[23] Vyskocil, A, Thuot, R, Turcot, A, Peak exposures to styrene in Quebec fibreglass reinforced plastic industry. In: Marklund, S, ed. lit. - Exposure assessment in epidemiology and practice. Stockholm: National Institute for Working Life. (2001) 316-318. 